\title{
Update on the role of modified release mesalamine in the management of ulcerative colitis and Crohn's disease
}

This article was published in the following Dove Press journal:

Clinical and Experimental Gastroenterology

7 December 2009

Number of times this article has been viewed

\author{
Glen A Doherty \\ Mark A Peppercorn \\ Center for Inflammatory Bowel \\ Disease, Beth Israel Deaconess \\ Medical Center and Harvard Medical \\ School, Boston MA, USA
}

\begin{abstract}
ASA) remain a key first-line therapy for patients with ulcerative colitis (UC). A range of 5-ASA preparations is available and Eudragit- $\mathrm{S}^{\circledR}$ coated modified release formulations of mesalamine, such as Asacol ${ }^{\circledR}$, remain among the most popular choices. We here review the current understanding of the mechanism of action of 5-ASA in inflammatory bowel disease. We evaluate evidence supporting the efficacy and safety of modified release mesalamine for both induction and remission maintenance in UC, including a review of the data from the recent ASCEND studies. We also examine the controversial issue of the role of mesalamine in treatment of Crohn's disease (CD) and highlight data supporting its use following surgically induced remission of CD. Evidence supporting the use of mesalamine as prophylaxis for colorectal cancer and dysplasia will be considered. Finally, recent developments in our understanding of how to use modified release mesalamine in a safe and cost-effective manner are evaluated, including discussion of the importance of studying patient non-adherence as a key component of future studies in this area.
\end{abstract}

Keywords: mesalamine (mesalazine), 5-aminosalicyclate, ulcerative colitis, Crohn's disease, modified release

\section{Introduction}

The therapeutic activity of 5-aminosalicyclates (5-ASA) in inflammatory bowel disease (IBD) was first demonstrated by the use of orally administered sulfasalazine (which is cleaved to its constituent 5-ASA and sulfapyridine moieties by the action of colonic microflora). ${ }^{1}$ While sulfasalazine is effective for induction and remission of maintenance in ulcerative colitis (UC), it is poorly tolerated (particularly at higher doses). Most toxicity results from the sulfa component, which is largely systemically absorbed, while 5-ASA remains predominantly in the colon. ${ }^{2}$ Indeed it was this observation that led to the hypothesis that 5-ASA was the active therapeutic component and this was confirmed in studies using enemas of the individual constituents. ${ }^{3}$ Several alternative strategies have been employed to direct delivery of 5-ASA to the distal intestine including the use of carrier molecules (as employed in the formulation of balsalazide) or the use of dimeric 5-ASA such as olsalazine; however arguably the more popular strategy has been the use of altered release formulations of mesalamine (or mesalazine), the name used for 5-ASA when it is employed alone as a drug. Two broad formulation strategies have been employed; the use of ethyl cellulose coated microgranules employed in the prototype prolonged release formulation Pentasa ${ }^{\circledR}$ and the use of acrylic enteric coating in formulations such as $\mathrm{Asacol}^{\circledR}$, Claversal ${ }^{\circledR}$ and Salofalk ${ }^{\circledR}$. We will here focus attention more specifically on Eudragit- $\mathrm{S}^{\circledR}$ coated modified release mesalamine 
marketed as Asacol ${ }^{\circledR}$ or Asacolon ${ }^{\circledR}$. We will review briefly data relating to the pharmacology of this preparation before focusing attention on studies of its use for both induction and remission maintenance in UC and Crohn's disease (CD). We will also look at data on safety and tolerability and the evidence to support 5-ASA use for chemoprophylaxis of colorectal neoplasia. We will concentrate particular attention on recent studies and conclude with a summary of our views on the place of modified release mesalamine in current IBD therapy.

\section{Pharmacology of modified release mesalamine}

Modified release mesalamine $\left(\right.$ Asacol $\left.^{\circledR}\right)$ ensures active drug reaches its principal site of action in the colon by use of a delivery system that involves coating of the active drug in a synthetic polymer. The coating consists of an 80 to $130 \mu \mathrm{m}$ layer of Eudragit- $\mathrm{S}^{\circledR}$, a resin containing methacrylic acid and methyl methacrylic acid in a 1:2 ratio. This acrylic resin layer is soluble at a $\mathrm{pH}$ of 7 or greater, with the result that drug release therefore occurs in the terminal ileum, the initial site during transit through the gastro-intestinal tract where luminal $\mathrm{pH}$ exceed neutral. While significant variations in colonic 5-ASA delivery between agents have been observed, modified release mesalamine appears to achieve satisfactory concentrations of mesalamine in colonic tissue. ${ }^{4}$ Significant systemic 5-ASA absorption occurs with all oral preparations and absorbed mesalamine is principally inactivated by acetylation in the liver with subsequent urinary excretion of metabolites. ${ }^{5}$ Most orally administered modified release mesalamine is, however, excreted by the fecal route. ${ }^{6}$ The pharmacokinetics of delayed release mesalamines do not appear altered by the use of acid suppressants ${ }^{7}$ and are not altered significantly in patients with diarrhea. ${ }^{8}$

\section{Mechanism of action of 5-ASA}

The mechanism of action of mesalamine is far from entirely understood, although a growing understanding of the molecular action of 5-ASA agents has been emerging. It is now well established that 5-ASA drugs have effects on the production and action of a number of key pro-inflammatory cytokines. 5-ASA drugs appear to impair binding of interferon-gamma (IFN- $\gamma$ ) to its receptor ${ }^{9}$ and disrupt the action of this key pro-inflammatory chemokine, ${ }^{10}$ including blocking of its detrimental effects on gut barrier function. ${ }^{11}$ 5-ASA agents reduce ex vivo production of interleukin-1 beta (IL-1 $\beta$ ) in IBD mucosal biopsies ${ }^{12,13}$ and by circulating peripheral blood monocytes $^{14}$ and also appear to impair the production of interleukin 2 (IL-2) with consequent effects on proliferation of T-lymphocytes. ${ }^{15}$ In addition to their effects on key cytokines, alterations in other key mediators of inflammation have also been described. 5-ASA agents have been noted to have a significant impact on production and activity of eicosanoids - arachidonic acid-derived signaling molecules with important vascular and immunoregulatory effects. 5-aminosalicylic acid reduced ex vivo generation of $\mathrm{PGE}_{2}$ and $\mathrm{LTB}_{4}$ by colonic mucosa from UC patients in one study ${ }^{16}$ and was noted to reduce $\mathrm{LTB}_{4}$ in another study (where no change in $\mathrm{PGE}_{2}$ was detected) with an associated reduction in $\mathrm{LTB}_{4}$ to $\mathrm{PGE}_{2}$ ratio. ${ }^{17}$ Whether these alterations are fundamental to the action of 5-ASA (or merely co-incidental to decreased inflammation by other mechanisms) remains debatable.

There has been interest in the effects of mesalamine on free radical production, another potential mechanism for modulation of intestinal inflammation by these agents. 5-ASA may act as scavengers of superoxide free radicals produced by inflammatory cells ${ }^{18}$ and in some studies have shown the ability to abrogate oxidant induced apoptosis of intestinal epithelial cells, with positive associated effects on mucosal barrier integrity. ${ }^{19}$

Exciting recent studies have offered a more profound insight into the precise molecular mechanisms for the antiinflammatory activity of 5-ASA, namely their ability to activate peroxisome proliferators-activated receptor-gamma (PPAR- $\gamma) .{ }^{20}$ PPARs are nuclear receptors which regulate gene expression. PPAR- $\gamma$ is expressed at high levels in colonic epithelium and appears important in maintenance of mucosal integrity and regulation of immune activation in the intestinal mucosa. However, PPAR activation may only be a piece of the jigsaw and changes in the balance of angiogenic factors in a rat model of UC have now also been elucidated. ${ }^{21}$ Recent intriguing data have also highlighted a potential role for 5 -ASA in altering gene expression by enteric microflora, ${ }^{22}$ a novel hypothesis which could open a new avenue in our understanding of the mechanism of action of these drugs.

Whatever the precise mechanism of action of these agents, there is abundant evidence that they exert a significant in vivo anti-inflammatory effect in patients with IBD. We will proceed therefore to review this evidence with particular focus on the efficacy of modified release mesalamine in a therapeutic setting.

\section{Efficacy in treatment of UC}

\section{Remission induction in UC}

The therapeutic activity of delayed release mesalamine for remission induction in UC has been observed in 
placebo-controlled comparisons. An initial study involved 87 patients with mild to moderately active UC randomized to receive Asacol ${ }^{\circledR} 4.8 \mathrm{~g} / \mathrm{day}, 1.6 \mathrm{~g} /$ day or placebo. Complete response was observed in $24 \%$ of patients receiving $4.8 \mathrm{~g} /$ day of mesalamine compared to $5 \%$ in the placebo group (with partial response in $50 \%$ versus $13 \%$ with placebo, $P<0.001) .{ }^{23}$ No significant difference with placebo was observed for the $1.6 \mathrm{~g} /$ day dose, though the numbers randomized to this arm were small $(n=11)$ and the comparison was likely underpowered. A subsequent multi-center trial made a placebo-controlled comparison of modified release mesalamine at two doses $(2.4 \mathrm{~g} /$ day and $1.6 \mathrm{~g} /$ day $)$ to placebo, with 158 patients with mild to moderate UC randomized. This study demonstrated significant improvement by week 6 with both doses of mesalamine ( $P=0.03$ for comparison with $1.6 \mathrm{~g} /$ day dose and $P=0.003$ with $2.4 \mathrm{~g} /$ dose), however only at the $2.4 \mathrm{~g} /$ dose was a clear difference observed in the proportion of patients who showed worsening $(50 \%$ in placebo group compared to $19 \%$ with mesalamine $2.4 \mathrm{~g} /$ day, $P=0.003) .{ }^{24}$

Early comparative studies demonstrated that Eudragit coated mesalamine showed similar efficacy to sulfasalazine in patients with active UC but was better tolerated. ${ }^{25} \mathrm{Com}$ parative studies followed with other 5-aminosalicylates. An initial randomized comparison of balsalazide $6.75 \mathrm{~g} / \mathrm{day}$ and mesalamine $2.4 \mathrm{~g}$ /day in patients with active UC demonstrated higher rates of complete remission at 12 weeks with balsalazide $(62 \%$ versus $37 \%) .{ }^{26}$ However, a subsequent larger trial of 154 patients did not detect a significant difference in remission rates at 8 weeks between patients receiving balsalazide $6.75 \mathrm{~g}$ /day and modified release mesalamine $2.4 \mathrm{~g} /$ day. $^{27}$

More recent studies of modified release mesalamine in active UC have focused on dose considerations, co-inciding with development of a new $800 \mathrm{mg}$ modified release tablet marketed in the United States as Asacol HD ${ }^{\circledR}$. Three studies have now evaluated the comparative efficacy of modified release mesalamine $2.4 \mathrm{~g}$ /day (dosed with a traditional $400 \mathrm{mg} \mathrm{Asacol}{ }^{\circledR}$ tablet) and $4.8 \mathrm{~g} /$ day (dosed with the new $800 \mathrm{mg}$ HD tablet). The first of these studies, ASCEND I, did not identify any overall difference in improvement at week 6 in 301 patients with mild to moderately active UC..$^{28}$ However, subgroup analysis in this study suggested an advantage to the higher dose specifically for patients with moderate (as distinct from mild) disease. The second study (ASCEND II) therefore focused on this subgroup (though patients with mild disease were still recruited). ${ }^{29}$ In 268 patients randomized with moderately active disease overall improvement (defined as complete remission or clinical response) at week 6 was observed in $72 \%$ treated with mesalamine $4.8 \mathrm{~g} /$ day compared to $59 \%$ treated with the $2.4 \mathrm{~g} /$ day dose $(P=0.036)$. The results of a final study (ASCEND III) have recently also been reported.$^{30}$ In this study 772 patients with moderately severe UC were randomized to an identical treatment regimen with remission at week 6 somewhat more common in the high dose group ( $43 \%$ compared to $35 \%, P=0.04$ ), although treatment success overall (the primary end-point) was not significantly different between the two groups. Interestingly, an advantage to high dose therapy was observed in the sub-group of patients previously treated for UC compared to treatment naïve/newly diagnosed patients. Table 1 summarizes the results of the principal controlled trials of the use of modified release mesalamine for remission induction in ulcerative colitis.

\section{Remission maintenance in UC}

The efficacy of modified release mesalamine for maintenance of remission has also been extensively evaluated both in comparison with placebo and in comparisons with other 5-ASA. An initial multi-center study evaluated the effectiveness of maintenance doses of mesalamine $1.6 \mathrm{~g} /$ day and $0.8 \mathrm{~g}$ /day in a placebo controlled comparison. ${ }^{31} 264$ patients with UC in remission for 1 month were randomized with an end-point of endoscopic remission at 6 months defining treatment success. In both intention to treat and per protocol analysis mesalamine at both doses was significantly better than placebo for remission maintenance. Remission was maintained in $70.1 \%$ ( $1.6 \mathrm{~g} /$ day) and $63.3 \%$ (0.8 g/day) compared to $48.3 \%$ in the placebo group in the intention to treat analysis $(P=0.05$ for comparison with $0.8 \mathrm{~g} /$ day dose, $P=0.005$ for comparison with $1.6 \mathrm{~g} /$ day dose) but no significant difference between the two doses of mesalamine was detectable. A subsequent study suggested that the addition of twice weekly rectal mesalamine $4 \mathrm{~g}$ to maintenance oral Asacol ${ }^{\circledR} 1.6 \mathrm{~g} /$ day significantly reduced the risk or relapse at one year (from $69 \%$ with oral therapy alone to $39 \%$ with combination treatment, $P=0.036$ ). ${ }^{32}$

A number of studies have compared modified release mesalamine to sulfasalazine in maintenance therapy. Two early studies both showed equivalence of modified release mesalamine in remission maintenance in UC. ${ }^{33,34}$ A subsequent larger study randomized one hundred patients with a longer duration of follow up. This study demonstrated that mesalamine doses of 0.8 and $1.6 \mathrm{~g}$ /day were equally effective to sulfasalazine 2 to $4 \mathrm{~g}$ /day in remission maintenance with relapse rates at 48 weeks (primary end point) of 38 and $39 \%$ respectively. ${ }^{35}$ 
Table I Summary of controlled trials of modified release mesalamine for induction of remission in ulcerative colitis (UC)

\begin{tabular}{|c|c|c|c|c|c|c|}
\hline $\begin{array}{l}\text { Study } \\
\text { author }\end{array}$ & $\begin{array}{l}\text { Number } \\
\text { randomized }\end{array}$ & Treatment arm & $\begin{array}{l}\text { Comparator } \\
\text { arm }\end{array}$ & Response & Remission & Comments \\
\hline Schroeder ${ }^{23}$ & $\mathrm{n}=87$ & $\begin{array}{l}\text { Mesalamine } 4.8 \mathrm{~g} \text { or } \\
1.6 \mathrm{~g} \text { for } 6 \text { weeks }\end{array}$ & Placebo & $\begin{array}{l}50 \%(4.8 \mathrm{~g}) \\
18 \%(1.6 \mathrm{~g}) \\
13 \% \text { (placebo) }\end{array}$ & $\begin{array}{l}24 \%(4.8 \mathrm{~g}) \\
9 \%(\mathrm{l} .6 \mathrm{~g}) \\
5 \% \text { (placebo) }\end{array}$ & $4.8 \mathrm{~g}$ dose superior to placebo \\
\hline Sninsky ${ }^{24}$ & $n=|3|$ & $\begin{array}{l}\text { Mesalamine } 2.4 \mathrm{~g} \text { or } \\
1.6 \mathrm{~g} \text { for } 6 \text { weeks }\end{array}$ & Placebo & $\begin{array}{l}49 \%(2.4 \mathrm{~g}) \\
43 \%(1.6 \mathrm{~g}) \\
23 \% \text { (placebo) }\end{array}$ & & $\begin{array}{l}\text { Per protocol analysis. } \\
\text { Both doses superior to } \\
\text { placebo }\end{array}$ \\
\hline Green $^{37}$ & $\mathrm{n}=101$ & $\begin{array}{l}\text { Mesalamine } 2.4 \mathrm{~g} \\
\text { for up to } 12 \text { weeks }\end{array}$ & $\begin{array}{l}\text { Balsalazide } \\
6.75 \mathrm{~g}\end{array}$ & & $\begin{array}{l}62 \%(\mathrm{Bal}) \\
37 \%(\mathrm{Mes})\end{array}$ & $\begin{array}{l}\text { ABACUS Induction Trial } \\
\text { Balsalazide appeared superior } \\
\text { to mesalamine }\end{array}$ \\
\hline Levine $^{27}$ & $\mathrm{n}=154$ & $\begin{array}{l}\text { Mesalamine } 2.4 \mathrm{~g} \\
\text { for } 8 \text { weeks }\end{array}$ & $\begin{array}{l}\text { Balsalazide } \\
6.75 \mathrm{~g} \\
\text { or } 2.25 \mathrm{~g}\end{array}$ & & $\begin{array}{l}20 \% \text { (Mes) } \\
23 \%(\text { Bal 6.75) } \\
19 \%(\text { Bal 2.25) }\end{array}$ & $\begin{array}{l}\text { No sig. difference noted } \\
\text { between balsalazide } 6.75 \mathrm{~g} \\
\text { and mesalamine } 2.4 \mathrm{~g}\end{array}$ \\
\hline Hanauer $^{28}$ & $\mathrm{n}=30 \mathrm{I}$ & $\begin{array}{l}\text { Mesalamine } 4.8 \mathrm{~g} \\
\text { for } 6 \text { weeks }\end{array}$ & $\begin{array}{l}\text { Mesalamine } \\
2.4 \mathrm{~g}\end{array}$ & $\begin{array}{l}56 \%(4.8 \mathrm{~g}) \\
51 \%(2.4 \mathrm{~g})\end{array}$ & & $\begin{array}{l}\text { ASCEND I includes patients } \\
\text { with mild and moderate UC }\end{array}$ \\
\hline Hanauer $^{29}$ & $\mathrm{n}=386$ & $\begin{array}{l}\text { Mesalamine } 4.8 \mathrm{~g} \\
\text { for } 6 \text { weeks }\end{array}$ & $\begin{array}{l}\text { Mesalamine } \\
2.4 \mathrm{~g}\end{array}$ & $\begin{array}{l}72 \%(4.8 \mathrm{~g}) \\
59 \%(2.4 \mathrm{~g})\end{array}$ & $\begin{array}{l}20 \%(4.8 \mathrm{~g}) \\
18 \%(2.4 \mathrm{~g})\end{array}$ & $\begin{array}{l}\text { ASCEND II rates for } \mathrm{n}=\mathbf{2 8 6} \\
\text { with moderate disease only }\end{array}$ \\
\hline Sandborn ${ }^{30}$ & $\mathrm{n}=772$ & $\begin{array}{l}\text { Mesalamine } 4.8 \mathrm{~g} \\
\text { for } 6 \text { weeks }\end{array}$ & $\begin{array}{l}\text { Mesalamine } \\
2.4 \mathrm{~g}\end{array}$ & $\begin{array}{l}70 \%(4.8 \mathrm{~g}) \\
66 \%(2.4 \mathrm{~g})\end{array}$ & $\begin{array}{l}43 \%(4.8 \mathrm{~g}) \\
35 \%(2.4 \mathrm{~g})\end{array}$ & $\begin{array}{l}\text { ASCEND III only patients with } \\
\text { moderate disease enrolled }\end{array}$ \\
\hline
\end{tabular}

Abbreviations: Mes, mesalamine; Bal, balsalazide.

A single randomized study has been reported which compared the relative efficacy of olsalazine and mesalamine. ${ }^{36}$ One hundred patients in remission with UC were randomized to olsalazine $1 \mathrm{~g} /$ day or mesalamine $\left(\mathrm{Asacol}^{\circledR}\right) 1.2 \mathrm{~g} /$ day. Treatment failure at 12 months was observed in $24 \%$ in the olsalazine group compared to $46 \%$ in the mesalamine group $(P=0.025)$. The relapse rates observed at 1 year (only $12 \%$ in the olsalazine group) were less in this single center study than those observed in other similar comparative studies. For example, in a comparative multi-center study of remission maintenance with balsalazide ( $3 \mathrm{~g} /$ day) and modified release mesalamine $1.2 \mathrm{~g} /$ day relapse rates of $42 \%$ in both treatment groups were reported at 12 month follow-up. ${ }^{37}$

A recent development in technology for mesalamine delivery has been the development of the multimatrix system (MMX), a formulation system which comprises lipophilic and hydrophilic excipients enclosed within a $\mathrm{pH}$-dependent coating to allow gradual release of active drug along the colon. ${ }^{38}$ The MMX mesalamine $\left(\right.$ Lialda $^{\circledR}$ ) formulation has demonstrated efficacy for both induction and maintenance in $\mathrm{UC}^{39,40}$ and results of a head to head comparison with modified release mesalamine for remission maintenance have recently been reported. ${ }^{41}$ This study randomized 331 patients with UC to receive either modified release mesalamine $\left(\right.$ Asacol $\left.^{\circledR}\right) 2.4 \mathrm{~g} /$ day with twice daily dosing or MMX 5-ASA $2.4 \mathrm{~g} /$ day with once daily dosing with appropriate placebo controls in each case. The proportion of patients in clinical remission at 1 year was similar in both groups (66\% versus $68 \%$ ) with combined rates of clinical and endoscopic remission also similar. Adverse events did not differ between the two study groups. The principal controlled trials for remission maintenance in UC with modified release mesalamine are shown in Table 2.

In summary, therefore, there is a significant body of evidence from randomized controlled trials of the efficacy of modified release mesalamine in both induction and maintenance of remission in UC. This agent generally appears at least as effective as other 5-ASA compounds at comparable doses. Recent developments in 5-ASA delivery technology have not enhanced its effectiveness compared to traditional 5-ASA formulations, though the possibility of once daily dosing may impact on compliance and patient preference.

\section{Efficacy in treatment of CD}

While there is a strong general consensus about the important role of 5-ASA in general and mesalamine preparations in particular in the treatment of $\mathrm{UC}$, the proper place of mesalamine in $\mathrm{CD}$ therapy is a much more contentious issue.

There has been only one published randomized study of the use of modified release mesalamine in treatment of active $\mathrm{CD} .{ }^{42}$ Patients with mild to moderately active ileo-colonic CD were randomized to receive mesalamine $3.2 \mathrm{~g} /$ day $(\mathrm{n}=20)$ 
Table 2 Summary of controlled trials of modified release mesalamine for maintenance of remission in ulcerative colitis

\begin{tabular}{|c|c|c|c|c|c|}
\hline $\begin{array}{l}\text { Study } \\
\text { author }\end{array}$ & $\begin{array}{l}\text { Number } \\
\text { randomized }\end{array}$ & Treatment arm & Comparator arm & Remission & Comments \\
\hline $\begin{array}{l}\text { Mesalamine } \\
\text { Study Group }{ }^{31}\end{array}$ & $\mathrm{n}=264$ & $\begin{array}{l}\text { Mesalamine } 1.6 \mathrm{~g} \text { or } \\
0.8 \mathrm{~g} \text { for } 6 \text { months }\end{array}$ & Placebo & $\begin{array}{l}70 \%(1.6 \mathrm{~g}) \\
63 \%(0.8 \mathrm{~g}) \\
48 \% \text { (placebo) }\end{array}$ & $\begin{array}{l}\text { Intention to treat } \\
\text { analysis Both doses } \\
\text { superior to placebo }\end{array}$ \\
\hline Riley 35 & $\mathrm{n}=100$ & $\begin{array}{l}\text { Mesalamine } 0.8-1.6 \mathrm{~g} \\
\text { for } 48 \text { weeks }\end{array}$ & Sulfasalazine $2-4 \mathrm{~g}$ & $\begin{array}{l}62 \% \text { (Mes) } \\
61 \%(\mathrm{SSZ})\end{array}$ & $\begin{array}{l}\text { Treatment equivalence } \\
\text { demonstrated }\end{array}$ \\
\hline d'Albasio 32 & $\mathrm{n}=69$ & $\begin{array}{l}\text { Mesalamine } 1.6 \mathrm{~g} \text { with } \\
\text { twice weekly } 5 \text {-ASA } \\
\text { enema for } 12 \text { months }\end{array}$ & Mesalamine $1.6 \mathrm{~g}$ & $\begin{array}{l}61 \% \text { (combo) } \\
31 \% \text { (oral) }\end{array}$ & $\begin{array}{l}\text { Combination therapy } \\
\text { superior to oral } \\
\text { mesalamine alone }\end{array}$ \\
\hline Courtney ${ }^{36}$ & $\mathrm{n}=100$ & $\begin{array}{l}\text { Mesalamine } 1.2 \mathrm{~g} \text { for } \\
12 \text { months }\end{array}$ & Olsalazine I g & $\begin{array}{l}54 \% \text { (Mes) } \\
76 \% \text { (Ols) }\end{array}$ & $\begin{array}{l}\text { Olsalazine superior to } \\
\text { mesalamine }\end{array}$ \\
\hline Green $^{37}$ & $\mathrm{n}=99$ & $\begin{array}{l}\text { Mesalamine } 1.2 \mathrm{~g} \text { for } \\
12 \text { months }\end{array}$ & Balsalazide $3.0 \mathrm{~g}$ & $\begin{array}{l}58 \%(\text { Mes) } \\
58 \%(\mathrm{Bal})\end{array}$ & $\begin{array}{l}\text { Treatment equivalence } \\
\text { demonstrated }\end{array}$ \\
\hline Prantera $^{41}$ & $n=331$ & $\begin{array}{l}\text { Mesalamine } 2.4 \mathrm{~g} \text { for } \\
12 \text { months }\end{array}$ & MMX 5-ASA $2.4 \mathrm{~g}$ & $\begin{array}{l}66 \% \text { (Mes) } \\
68 \% \text { (MMX) }\end{array}$ & $\begin{array}{l}\text { Treatment equivalence } \\
\text { demonstrated }\end{array}$ \\
\hline
\end{tabular}

Abbreviations: Mes, mesalamine; Bal, balsalazide; SSZ, sulfasalazine; Ols, olsalazine; MMX, multimatrix formulation.

or placebo $(\mathrm{n}=18)$. The study endpoints were remission $($ CDAI $<150)$ or response $($ CDAI $>150$ with $>70$ point reduction from baseline) at 16 weeks. Complete response (remission) was observed in $45 \%$ in the treatment group compared to $22 \%$ in the placebo group where treatment failure was seen in $72 \%$ compared to $35 \%$ of the mesalaminetreated patients.

These impressive differences have not, however, been reproduced by larger studies and systematic review has failed to identify convincing evidence for the effectiveness of 5-aminosalicylates for treatment of active CD. ${ }^{43}$ Indeed a recent meta-analysis suggested that there was no evidence to support the use of 5-ASA in the maintenance of medically induced remission in CD. ${ }^{44}$ However the situation may be somewhat different with surgically induced remission in CD. ${ }^{45}$ While most of the studies evaluating the use of mesalamine in post-operative prophylaxis have made use of either prolonged release (ethyl cellulose) or Eudragit- $\mathrm{L}^{\circledR}$ coated preparations, some of the most encouraging studies have evaluated the activity of Eudragit- $\mathrm{S}^{\circledR}$ coated modified release mesalamine $\left(\right.$ Asacol $\left.^{\circledR}\right)$. An initial randomized study of the effect of mesalamine $2.4 \mathrm{~g}$ /day following first intestinal resection for $\mathrm{CD}$ demonstrated a dramatic difference in both the rates of endoscopic recurrence and symptomatic (clinical) recurrence at 24 months with mesalamine. ${ }^{46}$ However the study has been criticized due to the absence of an adequate placebo control with consequent concerns about bias, due to inadequate allocation concealment. A subsequent randomized placebo controlled trial by the same authors evaluated the relative efficacy of modified release mesalamine
$4.0 \mathrm{~g} /$ day compared to $2.4 \mathrm{~g}$ /day when given as post-operative prophylaxis. ${ }^{47}$ The study $(\mathrm{n}=101)$ did detect a reduction in the primary end-point, the number of patients with any degree of endoscopic recurrence (Rutgeerts score $>0 ; 62 \%$ in the $4.0 \mathrm{~g}$ group versus $46 \%$ in the $2.4 \mathrm{~g} /$ day group, $P<0.04$ ). No significant differences were detected, however, in the rates of severe endoscopic recurrence or clinical recurrence at 12 months.

A recent meta-analysis of the effectiveness of a range of interventions for post-operative recurrence has suggested that there is evidence for a modest reduction in the risk of both clinical and endoscopic recurrence with use of mesalamine preparations when used for prevention of post-operative CD recurrence. ${ }^{48}$ The number needed to treat to prevent a single clinical recurrence is 12 , which raises concerns about the cost-effectiveness of mesalamine in this context. On the other hand, it can be argued that mesalamine is safe and well tolerated, in contrast to other agents suitable for use in prevention of CD recurrence. Indeed, safety issues with mesalamine, especially those relevant to modified release formulation are what we will go on to consider next.

\section{Safety and tolerability in IBD}

Data from controlled trials have showed that modified release mesalamine is generally well tolerated in treatment of IBD. A slight excess of gastro-intestinal side-effects such as nausea, dyspepsia and diarrhea has been reported in some placebo controlled trials (see Table 3 ) though without a significant dose relationship. ${ }^{24}$ However, in larger long term trials of modified release mesalamine dosed at $4.8 \mathrm{~g}$ /day 
Table 3 Common adverse effects of delayed release mesalamine in a large randomized placebo controlled trial ${ }^{24}$

\begin{tabular}{llll}
\hline $\begin{array}{l}\text { Adverse } \\
\text { effect }\end{array}$ & Placebo & $\begin{array}{l}\text { Mesalamine } \\
\text { I.6 g/day }\end{array}$ & $\begin{array}{l}\text { Mesalamine } \\
\mathbf{2 . 4} \text { g/day }\end{array}$ \\
\hline Vomiting & $2 \%$ & $2 \%$ & $0 \%$ \\
Nausea & $2 \%$ & $2 \%$ & $4 \%$ \\
Dyspepsia & $0 \%$ & $0 \%$ & $2 \%$ \\
Diarrhea & $0 \%$ & $0 \%$ & $4 \%$ \\
Gas & $4 \%$ & $2 \%$ & $4 \%$ \\
Rash & $4 \%$ & $4 \%$ & $0 \%$ \\
Headache & $14 \%$ & $15 \%$ & $4 \%$ \\
\hline
\end{tabular}

treatment is well tolerated with low rates of withdrawal due to adverse effects. ${ }^{29,30}$ Meta-analysis suggests that the tolerability of other 5-ASA including mesalamine is generally superior to sulfasalazine ${ }^{49}$ and that withdrawals due to adverse events are not significantly greater than for placebo. ${ }^{49}$ Rare serious adverse events associated with delayed release mesalamine have, however, been reported including blood dyscrasias, pancreatitis, pneumonitis, pericarditis and hepatitis. A paradoxical worsening of colitis is observed infrequently with all 5-ASA drugs, a phenomenon that is not well understood. One of the most feared and contentious side effects of 5-ASA is the rare risk of interstitial nephritis. While chronic interstitial nephritis has been reported in association with modified release mesalamine therapy, ${ }^{50}$ there have also been reports in IBD patients in the absence of 5-ASA therapy ${ }^{51}$ and both disease activity and 5-ASA therapy have been associated with renal tubular dysfunction in IBD patients. ${ }^{52}$ To date there is no evidence of any difference between 5-ASA preparations in terms of risk of renal dysfunction. ${ }^{53,54}$ While some authors have made recommendations for close monitoring of renal function in IBD patients initiating 5-ASA therapy, ${ }^{55}$ this remains controversial and others have argued that renal dysfunction is exceptionally rare and that monitoring is not warranted. ${ }^{56}$

\section{Role in chemoprophylaxis of colorectal neoplasia}

While the principal reason for mesalamine prescribing remains the induction and maintenance of disease remission in IBD, particularly UC, there has been increasing interest into its potential role in prevention of neoplasia complicating chronic colitis. Few authors now dispute that there is an increase in the risk of colorectal cancer (CRC) in patients with UC and that the incidence increases progressively with disease duration, such that cancer risk may be as high as $8 \%$ by 20 years and $18 \%$ by 30 years from diagnosis of colitis. ${ }^{57}$ A number of epidemiological studies have suggested that 5-ASA use by UC patients maybe be associated with a reduced incidence of CRC. A nested case control analysis of data from a large primary care database in the UK found the odds ratio (OR) of CRC was decreased in regular (compared to irregular) 5-ASA users (adjusted OR $0.60,95 \%$ confidence interval $[\mathrm{CI}] 0.38$ to 0.96 ) and was negatively associated with the number of prescriptions for both sulfasalazine and mesalamine filled in the preceeding 12 months. ${ }^{58}$ Another UK case control study with over 100 cases of UC-associated CRC made similar findings with the OR of CRC significantly reduced with 5-ASA use, particularly mesalamine (OR $0.19,95 \%$ CI 0.06 to 0.61$){ }^{59}$ This study also highlighted that regular clinic visits with a hospital doctor were also protective and there has been debate about whether 5-ASA use/adherence is merely a surrogate for better compliance with other aspects of health maintenance. This may partially explain the failure of some other case control studies to identify a significant association between cancer risk and preceding 5-ASA use. ${ }^{60}$ It is possible that differences in the application of endoscopic surveillance for IBD associated dysplasia in different countries or geographical areas might influence how important an anti-neoplastic effect mesalamine or other 5-ASA have in a given population. The balance of evidence, however, appears to suggest that 5-ASA are protective in reducing risk of $\mathrm{CRC}$ but their effect on the incidence of dysplasia requires ongoing evaluation. ${ }^{61}$ Given the significant costs associated with treatment of CRC, it is important that the impact of 5-ASA be fully understood and factored into any pharmaco-economic analysis of their use. Indeed, this is an area that we will now go on to evaluate in more detail.

\section{Recent developments in use of modified release mesalamine}

There has been increasing focus recently on the pharmacoeconomic aspects of 5-ASA use in UC. Cost-effectiveness studies of 5-ASA therapies in UC have highlighted that both cost per flare prevented and cost per quality of life adjusted year (QALY) gained with maintenance 5-ASA treatment is substantial. It has even been suggested that 5-ASA maintenance may only be cost-effective in the case of sulfasalazine (where monthly drug costs are substantially lower than for other 5-ASA preparations). ${ }^{62}$ However, healthcare costs can vary substantially both regionally and from country to country and so the findings of such studies can be difficult to apply universally. For example a 
cost utility study performed in the UK which specifically examined the relative cost-effectiveness of high dose (HD) modified release mesalamine $\left(4.8 \mathrm{~g} /\right.$ day of Asacol $\mathrm{HD}^{\circledR}$ $800 \mathrm{mg}$ ) versus standard therapy with $2.4 \mathrm{~g} /$ day $\mathrm{Asacol}^{\mathbb{R}}$ with the standard $400 \mathrm{mg}$ preparation came to a very different conclusion. ${ }^{63}$ This analysis favored the use of HD mesalamine as more effective, less costly and based on a cost per QALY threshold of $£ 30,000$ reported a $72 \%$ likelihood that its use was cost-effective. A specific quality of life analysis (using the IBDQ index) on patients enrolled in the ASCEND I and II studies has certainly highlighted significant early improvements in IBDQ scores with modified release mesalamine therapy. ${ }^{64}$

Recent studies have also highlighted the crucial importance of non-adherence in the both the cost and utility of 5-ASA use. A recent systematic review of the impact of 5-ASA non-adherence in UC pays particular attention to the cost of associated flares. ${ }^{65}$ Based on data from six 5-ASA RCTs they observed relative risk of flare in excess of 3.65 in non-adherent patients. Despite the additional expenditure on medications in adherent patients, overall co-morbidity adjusted healthcare costs were greater in non-adherent individuals.

Given the high levels of non-compliance with maintenance therapy reported by UC patients, ${ }^{66}$ there has been significant interest in devising methods to improve adherence. Data on compliance in patients taking delayed release mesalamine have highlighted specific factors associated with non-compliance ${ }^{67}$ Logistic regression revealed 3-times daily dosing (OR, 3.1; 95\% CI, 1.8 to 8.4 ] and full-time employment (OR, 2.7; 95\% CI, 1.1 to 6.9 ) to be independent predictors of non-compliance. Interestingly, clinical depression was the only independent predictor of complete non-compliance (OR, $10.5 ; 95 \%$ CI, 1.8 to 79.0 ), highlighting the importance of identifying and treating co-morbid mood disorders in IBD patients in order to maximize the quality of their care. Based on this data, aiming for a once or twice daily dosing regime would certainly appear worthwhile. However, while dosing frequency certainly appears important other intervention may be considered to minimize non-adherence. Physician's time spent in education and use of other simple behavioral strategies may also constitute important adjuncts.$^{68}$ Non-adherence is clearly an important issue in how 5-ASA drugs are used, with both significant clinical and economic consequences. Future studies of 5-ASA should ideally ensure that nonadherence is included as a key outcome component.

As well as consolidating our understanding of how best to use mesalamine in treatment of $\mathrm{UC}$ and possibly in $\mathrm{CD}$, there may be additional novel therapeutic avenues that merit evaluation. Future studies may be useful to examine new indications for mesalamine outside of IBD therapy, including the use of modified release mesalamine in other inflammatory disorders of the colon such as diverticulitis. ${ }^{69}$ There has even been interest in potentially beneficial effects of the anti-inflammatory properties of mesalamine in functional bowel disorders. ${ }^{70}$

\section{Conclusion}

Modified release mesalamine $\left(\right.$ Asacol $^{\circledR}$ or Asacolon ${ }^{\circledR}$ ) remains among the most popular 5-ASA formulations currently in use for the treatment of IBD. There is a significant body of data from clinical trials that modified release mesalamine is more effective than placebo for both induction and remission maintenance in UC and this agent compares favorably with other 5-ASA in comparative studies. Several recent studies have been helpful in clarifying optimal use of this agent in UC. Recent data suggest that twice daily modified release mesalamine therapy with $4.8 \mathrm{~g}$ /day may be more effective than $2.4 \mathrm{~g}$ /day in remission induction in UC patients with disease of moderate severity, although the differential effect is modest at best. Recent maintenance studies demonstrate that at equivalent doses, twice daily modified release mesalamine is as effective as once daily MMX mesalamine. The choice between these agents is likely to be determined, therefore, by factors such as cost and patient preference. It remains to be seen, however, whether once daily dosing has a clinically significant advantage over twice daily dosing with regards to long-term rates of 5-ASA compliance. There is a paucity of data to support mesalamine use in treatment of active $\mathrm{CD}$ or in maintenance of medically induced remission. However, there are data for a modest benefit for mesalamine in maintenance of surgically induced remission, although the number needed to treat to prevent a single clinical recurrence is approximately twelve. There are insufficient studies to determine whether any 5-ASA formulation is superior to another in this context. The real question is whether use of mesalamine is cost-effective in the post-operative setting in $\mathrm{CD}$ and this issue remains open for debate and further study. There are conflicting data on the cost-effectiveness of mesalamine as maintenance treatment for $\mathrm{UC}$ and this is an area that merits further careful evaluation. Cost-effectiveness analysis should probably also incorporate an understanding of the likely chemo preventive properties of mesalamine, as this may be an important consideration in how and why these agents are used into the future. 


\section{Disclosures}

The authors disclose no conflicts of interest.

\section{References}

1. Peppercorn MA, Goldman P. The role of intestinal bacteria in the metabolism of salicylazosulfapyridine. J Pharmacol Exp Ther. 1972;181(3):555-562.

2. Peppercorn MA, Goldman P. Distribution studies of salicylazosulfapyridine and its metabolites. Gastroenterology. 1973;64(2):240-245.

3. Azad Khan AK, Piris J, Truelove SC. An experiment to determine the active therapeutic moiety of sulphasalazine. Lancet. 1977;2(8044):892-895.

4. De Vos M, Verdievel H, Schoonjans R, Praet M, Bogaert M, Barbier F. Concentrations of 5-ASA and Ac-5-ASA in human ileocolonic biopsy homogenates after oral 5-ASA preparations. Gut. 1992;33(10):1338-1342.

5. Lauritsen K, Laursen LS, Rask-Madsen J. Clinical pharmacokinetics of drugs used in the treatment of gastrointestinal diseases (Part II). Clin Pharmacokinet. 1990;19(2):94-125.

6. Staerk Laursen L, Stokholm M, Bukhave K, Rask-Madsen J, Lauritsen K. Disposition of 5-aminosalicylic acid by olsalazine and three mesalazine preparations in patients with ulcerative colitis: comparison of intraluminal colonic concentrations, serum values, and urinary excretion. Gut. 1990;31(11):1271-1276.

7. Wiltink EH, Mulder CJ, Stolk LM, Rietbroek R, Verbeek C, Tytgat GN. Absorption of oral mesalazine-containing preparations and the influence of famotidine on the absorption. Scand J Gastroenterol. 1990;25(6): $579-584$.

8. Rijk MC, van Schaik A, van Tongeren JH. Disposition of mesalazine from mesalazine-delivering drugs in patients with inflammatory bowel disease, with and without diarrhoea. Scand J Gastroenterol. 1992;27(10):863-868.

9. Crotty B, Rosenberg WM, Aronson JK, Jewell DP. Inhibition of binding of interferon-gamma to its receptor by salicylates used in inflammatory bowel disease. Gut. 1992;33(10):1353-1357.

10. Crotty B, Hoang P, Dalton HR, Jewell DP. Salicylates used in inflammatory bowel disease and colchicine impair interferon-gamma induced HLA-DR expression. Gut. 1992;33(1):59-64.

11. Di Paolo MC, Merrett MN, Crotty B, Jewell DP. 5-Aminosalicylic acid inhibits the impaired epithelial barrier function induced by gamma interferon. Gut. 1996;38(1):115-119.

12. Mahida YR, Lamming CE, Gallagher A, Hawthorne AB, Hawkey CJ. 5-Aminosalicylic acid is a potent inhibitor of interleukin 1 beta production in organ culture of colonic biopsy specimens from patients with inflammatory bowel disease. Gut. 1991;32(1):50-54.

13. Rachmilewitz D, Karmeli F, Schwartz LW, Simon PL. Effect of aminophenols (5-ASA and 4-ASA) on colonic interleukin-1 generation. Gut. 1992;33(7):929-932.

14. Bruin KF, Hommes DW, Jansen J, Tytgat GN, Wouter ten Cate J, van Deventer SJ. Modulation of cytokine release from human monocytes by drugs used in the therapy of inflammatory bowel diseases. Eur $J$ Gastroenterol Hepatol. 1995;7(8):791-795.

15. Stevens C, Lipman M, Fabry S, et al. 5-Aminosalicylic acid abrogates T-cell proliferation by blocking interleukin-2 production in peripheral blood mononuclear cells. J Pharmacol Exp Ther. 1995;272(1):399-406.

16. Eliakim R, Karmeli F, Chorev M, Okon E, Rachmilewitz D. Effect of drugs on colonic eicosanoid accumulation in active ulcerative colitis. Scand J Gastroenterol. 1992;27(11):968-972.

17. Schmidt C, Fels T, Baumeister B, Vetter H. The effect of 5-aminosalicylate and para-aminosalicylate on the synthesis of prostaglandin E2 and leukotriene B4 in isolated colonic mucosal cells. Curr Med Res Opin. 1996;13(7): 417-425.

18. Gionchetti P, Guarnieri C, Campieri M, et al. Scavenger effect of sulfasalazine, 5-aminosalicylic acid, and olsalazine on superoxide radical generation. Dig Dis Sci. 1991;36(2):174-178.

19. Sandoval M, Liu X, Mannick EE, Clark DA, Miller MJ. Peroxynitriteinduced apoptosis in human intestinal epithelial cells is attenuated by mesalamine. Gastroenterology. 1997;113(5):1480-1488.
20. Rousseaux C, Lefebvre B, Dubuquoy L, et al. Intestinal antiinflammatory effect of 5-aminosalicylic acid is dependent on peroxisome proliferatoractivated receptor-gamma. $J$ Exp Med. 2005;201(8):1205-1215.

21. Deng X, Tolstanova G, Khomenko T, et al. Mesalamine restores angiogenic balance in experimental ulcerative colitis by reducing expression of endostatin and angiostatin: Novel molecular mechanism for mesalamine's therapeutic action. J Pharmacol Exp Ther. 2009;331(3):1071-1078.

22. Kaufman J, Griffiths TA, Surette MG, Ness S, Rioux KP. Effects of mesalamine (5-aminosalicylic acid) on bacterial gene expression. Inflamm Bowel Dis. 2009;15(7):985-996.

23. Schroeder KW, Tremaine WJ, Ilstrup DM. Coated oral 5-aminosalicylic acid therapy for mildly to moderately active ulcerative colitis. A randomized study. N Engl J Med. 1987;317(26):1625-1629.

24. Sninsky CA, Cort DH, Shanahan F, et al. Oral mesalamine (Asacol ${ }^{\circledR}$ ) for mildly to moderately active ulcerative colitis. A multicenter study. Ann Intern Med. 1991;115(5):350-355.

25. Rachmilewitz D. Coated mesalazine (5-aminosalicylic acid) versus sulphasalazine in the treatment of active ulcerative colitis: a randomised trial. BMJ. 1989;298(6666):82-86.

26. Green JR, Lobo AJ, Holdsworth CD, et al. Balsalazide is more effective and better tolerated than mesalamine in the treatment of acute ulcerative colitis. The Abacus Investigator Group. Gastroenterology. 1998;114(1):15-22.

27. Levine DS, Riff DS, Pruitt R, et al. A randomized, double blind, doseresponse comparison of balsalazide $(6.75 \mathrm{~g})$, balsalazide $(2.25 \mathrm{~g})$, and mesalamine $(2.4 \mathrm{~g})$ in the treatment of active, mild-to-moderate ulcerative colitis. Am J Gastroenterol. 2002;97(6):1398-1407.

28. Hanauer SB, Sandborn WJ, Dallaire C, et al. Delayed-release oral mesalamine $4.8 \mathrm{~g} /$ day ( $800 \mathrm{mg}$ tablets) compared to $2.4 \mathrm{~g} /$ day $(400 \mathrm{mg}$ tablets) for the treatment of mildly to moderately active ulcerative colitis: The ASCEND I trial. Can J Gastroenterol. 2007;21(12):827-834.

29. Hanauer SB, Sandborn WJ, Kornbluth A, et al. Delayed-release oral mesalamine at $4.8 \mathrm{~g} /$ day $(800 \mathrm{mg}$ tablet $)$ for the treatment of moderately active ulcerative colitis: the ASCEND II trial. Am J Gastroenterol. 2005; 100(11):2478-2485.

30. Sandborn WJ, Regula J, Feagan BG, et al. Delayed-Release Oral Mesalamine $4.8 \mathrm{~g}$ /day ( $800 \mathrm{mg}$ tablet) is Effective for Patients with Moderately Active Ulcerative Colitis. Gastroenterology. 2009. [Epub ahead of print].

31. An oral preparation of mesalamine as long-term maintenance therapy for ulcerative colitis. A randomized, placebo-controlled trial. The Mesalamine Study Group. Ann Intern Med. 1996;124(2): 204-211.

32. d'Albasio G, Pacini F, Camarri E, et al. Combined therapy with 5 -aminosalicylic acid tablets and enemas for maintaining remission in ulcerative colitis: a randomized double-blind study. Am J Gastroenterol. 1997;92(7):1143-1147.

33. Dew MJ, Hughes P, Harries AD, Williams G, Evans BK, Rhodes J. Maintenance of remission in ulcerative colitis with oral preparation of 5-aminosalicylic acid. Br Med J (Clin Res Ed). 1982;285(6347):1012.

34. Dew MJ, Harries AD, Evans N, Evans BK, Rhodes J. Maintenance of remission in ulcerative colitis with 5-amino salicylic acid in high doses by mouth. Br Med J (Clin Res Ed). 1983;287(6384):23-24.

35. Riley SA, Mani V, Goodman MJ, Herd ME, Dutt S, Turnberg LA. Comparison of delayed-release 5-aminosalicylic acid (mesalazine) and sulfasalazine as maintenance treatment for patients with ulcerative colitis. Gastroenterology. 1988;94(6):1383-1389.

36. Courtney MG, Nunes DP, Bergin CF, et al. Randomised comparison of olsalazine and mesalazine in prevention of relapses in ulcerative colitis. Lancet. 1992;339(8804):1279-1281.

37. Green JR, Gibson JA, Kerr GD, et al. Maintenance of remission of ulcerative colitis: a comparison between balsalazide $3 \mathrm{~g}$ daily and mesalazine $1.2 \mathrm{~g}$ daily over 12 months. ABACUS Investigator group. Aliment Pharmacol Ther. 1998;12(12):1207-1216.

38. Baker DE. MMX mesalamine. Rev Gastroenterol Disord. 2006;6(3): 146-152. 
39. Kamm MA, Sandborn WJ, Gassull M, et al. Once-daily, high-concentration MMX mesalamine in active ulcerative colitis. Gastroenterology. 2007; 132(1):66-75; quiz 432-433.

40. Kamm MA, Lichtenstein GR, Sandborn WJ, et al. Randomised trial of once- or twice-daily MMX mesalazine for maintenance of remission in ulcerative colitis. Gut. 2008;57(7):893-902.

41. Prantera C, Kohn A, Campieri M, et al. Clinical trial: Ulcerative colitis maintenance treatment with 5-ASA - a 1-year, randomized multicentre study comparing MMX with Asacol. Aliment Pharmacol Ther. 2009;30(9):908-918.

42. Tremaine WJ, Schroeder KW, Harrison JM, Zinsmeister AR. A randomized, double-blind, placebo-controlled trial of the oral mesalamine (5-ASA) preparation, Asacol ${ }^{\circledR}$, in the treatment of symptomatic Crohn's colitis and ileocolitis. J Clin Gastroenterol. 1994;19(4):278-282.

43. Bergman R, Parkes M. Systematic review: the use of mesalazine in inflammatory bowel disease. Aliment Pharmacol Ther. 2006;23(7):841-855.

44. Akobeng AK, Gardener E. Oral 5-aminosalicylic acid for maintenance of medically-induced remission in Crohn's Disease. Cochrane Database Syst Rev. 2005;(1):CD003715.

45. Camma C, Giunta M, Rosselli M, Cottone M. Mesalamine in the maintenance treatment of Crohn's disease: a meta-analysis adjusted for confounding variables. Gastroenterology. 1997;113(5):1465-1473.

46. Caprilli R, Andreoli A, Capurso L, et al. Oral mesalazine (5-aminosalicylic acid; Asacol $\left.{ }^{\circledR}\right)$ for the prevention of post-operative recurrence of Crohn's disease. Gruppo Italiano per lo Studio del Colon e del Retto (GISC). Aliment Pharmacol Ther. 1994;8(1):35-43.

47. Caprilli R, Cottone M, Tonelli F, et al. Two mesalazine regimens in the prevention of the post-operative recurrence of Crohn's disease: a pragmatic, double-blind, randomized controlled trial. Aliment Pharmacol Ther. 2003;17(4):517-523.

48. Doherty G, Bennett G, Patil S, Cheifetz A, Moss AC. Interventions for prevention of post-operative recurrence of Crohn's disease. Cochrane Database Syst Rev. 2009;(4):CD006873.

49. Sutherland L, Macdonald JK. Oral 5-aminosalicylic acid for induction of remission in ulcerative colitis. Cochrane Database Syst Rev. 2006;(2): CD000543.

50. Popoola J, Muller AF, Pollock L, O’Donnell P, Carmichael P, Stevens P. Late onset interstitial nephritis associated with mesalazine treatment BMJ. 1998;317(7161):795-797.

51. Pardi DS, Tremaine WJ, Sandborn WJ, McCarthy JT. Renal and urologic complications of inflammatory bowel disease. Am J Gastroenterol. 1998;93(4):504-514

52. Schreiber S, Hamling J, Zehnter E, et al. Renal tubular dysfunction in patients with inflammatory bowel disease treated with aminosalicylate. Gut. 1997 Jun;40(6):761-766.

53. Gisbert JP, Gonzalez-Lama Y, Mate J. 5-Aminosalicylates and renal function in inflammatory bowel disease: a systematic review. Inflamm Bowel Dis. 2007 May;13(5):629-638.

54. Van Staa TP, Travis S, Leufkens HG, Logan RF. 5-aminosalicylic acids and the risk of renal disease: a large British epidemiologic study. Gastroenterology. 2004 Jun;126(7):1733-1739.

55. World MJ, Stevens PE, Ashton MA, Rainford DJ. Mesalazine-associated interstitial nephritis. Nephrol Dial Transplant. 1996 Apr;11(4): 614-621
56. Gisbert JP, Luna M, Gonzalez-Lama Y, et al. Effect of 5-aminosalicylates on renal function in patients with inflammatory bowel disease: 4-year follow-up study. Gastroenterol Hepatol. 2008 Oct;31(8):477-484.

57. Eaden JA, Abrams KR, Mayberry JF. The risk of colorectal cancer in ulcerative colitis: a meta-analysis. Gut. 2001 Apr;48(4):526-535.

58. van Staa TP, Card T, Logan RF, Leufkens HG. 5-Aminosalicylate use and colorectal cancer risk in inflammatory bowel disease: a large epidemiological study. Gut. 2005 Nov;54(11):1573-1578.

59. Eaden J, Abrams K, Ekbom A, Jackson E, Mayberry J. Colorectal cancer prevention in ulcerative colitis: a case-control study. Aliment Pharmacol Ther. 2000 Feb;14(2):145-153.

60. Terdiman JP, Steinbuch M, Blumentals WA, Ullman TA, Rubin DT. 5-Aminosalicylic acid therapy and the risk of colorectal cancer among patients with inflammatory bowel disease. Inflamm Bowel Dis. 2007 Apr;13(4):367-371.

61. Velayos FS, Terdiman JP, Walsh JM. Effect of 5-aminosalicylate use on colorectal cancer and dysplasia risk: a systematic review and metaanalysis of observational studies. Am J Gastroenterol. 2005 Jun;100(6): 1345-1353.

62. Yen EF, Kane SV, Ladabaum U. Cost-effectiveness of 5-aminosalicylic acid therapy for maintenance of remission in ulcerative colitis. $\mathrm{Am} \mathrm{J}$ Gastroenterol. 2008 Dec;103(12):3094-3105.

63. Buckland A, Bodger K. The cost-utility of high dose oral mesalazine for moderately active ulcerative colitis. Aliment Pharmacol Ther. 2008 Dec 1;28(11-12):1287-1296.

64. Irvine EJ, Yeh CH, Ramsey D, Stirling AL, Higgins PD. The effect of mesalazine therapy on quality of life in patients with mildly and moderately active ulcerative colitis. Aliment Pharmacol Ther. 2008 Dec 1;28(11-12):1278-1286.

65. Higgins PD, Rubin DT, Kaulback K, Schoenfield PS, Kane SV. Systematic review: impact of non-adherence to 5-aminosalicylic acid products on the frequency and cost of ulcerative colitis flares. Aliment Pharmacol Ther. 2009 Feb 1;29(3):247-257.

66. Rubin DT, Siegel CA, Kane SV, et al. Impact of ulcerative colitis from patients' and physicians' perspectives: Results from the UC: NORMAL survey. Inflamm Bowel Dis. 2009 Apr;15(4):581-588.

67. Shale MJ, Riley SA. Studies of compliance with delayed-release mesalazine therapy in patients with inflammatory bowel disease. Aliment Pharmacol Ther. 2003 Jul 15;18(2):191-198.

68. Hawthorne AB, Rubin G, Ghosh S. Review article: medication nonadherence in ulcerative colitis - strategies to improve adherence with mesalazine and other maintenance therapies. Aliment Pharmacol Ther. 2008 Jun;27(12):1157-1166.

69. Cohen HD, Das KM. The metabolism of mesalamine and its possible use in colonic diverticulitis as an anti-inflammatory agent. J Clin Gastroenterol. 2006 Aug;40 Suppl 3:S150-S154.

70. Corinaldesi R, Stanghellini V, Cremon C, et al. Effect of mesalazine on mucosal immune biomarkers in irritable bowel syndrome: a randomized controlled proof-of-concept study. Aliment Pharmacol Ther. 2009 Aug; 30(3):245-252.
Clinical and Experimental Gastroenterology

\section{Publish your work in this journal}

Clinical and Experimental Gastroenterology is an international, peerreviewed, open access journal, publishing all aspects of gastroenterology in the clinic and laboratory, including: Pathology, pathophysiology of gastrointestinal disease; Investigation and treatment of gastointes tinal disease; Pharmacology of drugs used in the alimentary tract;

\section{Dovepress}

Immunology/genetics/genomics related to gastrointestinal disease. This journal is indexed on CAS. The manuscript management system is completely online and includes a very quick and fair peer-review system. Visit http://www.dovepress.com/testimonials.php to read real quotes from published authors. 